J. Lake Sci. (湖泊科学), 2017, 29(1): 69-77

DOI 10. 18307/2017. 0108

(C) 2017 by Journal of Lake Sciences

\title{
洱海流域入湖河口湿地沉积物氮、磷、有机质分布及污染风险评价"
}

\author{
王书锦 ${ }^{1}$, 刘云根 ${ }^{1,2 * *}$, 张 超 ${ }^{3}$, 侯 磊 ${ }^{1,2}$, 王 妍 ${ }^{1,2}$ \\ (1: 西南林业大学环境科学与工程学院, 昆明 650224) \\ (2: 西南林业大学农村污水处理研究所, 昆明 650224) \\ (3: 西南林业大学林学院, 昆明 650224)
}

\begin{abstract}
摘 要: 以云南洱海罗时江河口湿地为典型对象,利用柱状底泥分层采样器采集罗时江河口湿地表层 $(0 \sim 10 \mathrm{~cm})$ 沉积物 样品,研究分析总氮 (TN)、总磷 (TP)、有机质 $(\mathrm{OM})$ 的空间分布特征,并对沉积物进行污染风险评价. 结果表明: 表层沉积 物 TP 含量在 $0.04 \sim 1.28 \mathrm{~g} / \mathrm{kg}$ 之间, 空间分布特征为: II 区> I 区, 水道 I > 水道 II ; TN 含量在 $0.33 \sim 2.96 \mathrm{~g} / \mathrm{kg}$ 之间, 空间 分布特征为: I 区 $>$ II 区, 水道 I > 水道 II , OM 含量在 32.43 233.03 g/ kg 之间, 空间分布表现为 I 区 $<$ II 区, 水道 $\mathrm{I}<$ 水道 II. 结合综合污染指数与有机指数评价法可知, 罗时江河口湿地表层沉积物氮、磷污染: I 区和水道 I 属于中度污染, II 区和水道 II 属于轻度污染; 有机污染: 水道 I 和水道 II 属于重度污染, I 区和 II 区属于中度污染. 罗时江河口湿地表层沉 积物空间分布受外源污染物、养殖活动和湿地水生植物的影响, 氮、磷外源输人以水道 I 为主, 有机质输人以水道 II 为主. 关键词: 洱海流域; 罗时江河口湿地;高原河口湿地;沉积物;氮;磷;有机质;空间分布; 风险评价
\end{abstract}

\section{Distribution and pollution risk assessment of nitrogen, phosphorus and organic matter in inlet rivers of Erhai Basin}

\author{
WANG Shujin $^{1}$, LIU Yungen ${ }^{1,2 * *}$, ZHANG Chao ${ }^{3}$, HOU Lei ${ }^{1,2} \&$ WANG Yan ${ }^{1,2}$ \\ (1: College of Environmental Science and Engineering, Southwest Forestry University, Kunming 650224, P.R.China) \\ (2: Research Institute of Rural Sewage Treatment, Southwest Forestry University, Kunming 650224, P.R. China) \\ (3: Forestry College, Southwest Forestry University, Kunming 650224, P.R. China)
}

\begin{abstract}
The estuarine wetland of Luoshi River, which flowed into Lake Erhai in Yunnan Plateau, is used to be studied as a typical research object. Sediment samples in the estuarine wetland of Luoshi River were collected by the cylindrical sediment sampler and taken from the surface layer $(0-10 \mathrm{~cm})$. The spatial distributions of the total nitrogen, total phosphorus and total organic matter were analyzed, and did the pollution risk assessment of sediments. The results showed that: The contents of total phosphorus (TP) in the surface sediments ranged from 0.04 to $1.28 \mathrm{~g} / \mathrm{kg}$, and the TP spatial distribution characteristics were lower in area I than area II , but higher in channel I than channel II. The content of total nitrogen ( TN) in the surface sediments ranged from 0.33 to $2.96 \mathrm{~g} / \mathrm{kg}$, and the TN spatial distribution characteristics were higher in area I than area II , and higher in channel I than channel II . The content of OM in the surface sediments ranged from 32.43 to $233.03 \mathrm{~g} / \mathrm{kg}$, and the OM spatial distribution characteristics were lower in area I than area II , and lower in channel I than channel II . Combined evaluation methods with the comprehensive pollution index and organic index to analyze the pollution of the total nitrogen and the total phosphorus in the surface sediments at the estuarine wetland of Luoshi River, results show that the pollution in area I and channel I was medium level, and the pollution in area II and channel II was mild level. The pollution of organic contaminants in channel I and channel II was heavy level, and the area I and area II was medium level. The spatial distribution of surface sediment at the estuarine wetland of Luoshi River was influenced by the external pollutant, the culture activity and the aquatic plant. Pollution in channel I was mainly sourced by input of nitrogen and phosphorus, and pollution in channel II was mainly dominated by organic matter.
\end{abstract}

Keywords: Erhai Basin; estuarine wetland of Luoshi River; plateau estuary wetland; sediments ; nitrogen ; phosphorus; organic

* 国家自然科学基金项目 (51469030,31560237,31460195) 资助.2016-01-09 收稿;2016-04-30 收修改稿. 王书锦 (1989 ), 男,硕士研究生;E-mail : haigui2018@163.com.

** 通信作者; E-mail:henryliu1008@163.com. 
matter; spatial distribution; risk assessment

河口湿地作为削减流域物质输入湖泊的最后天然屏障, 具有拦截人湖污染、恢复水陆生态系统功能、维 持湖泊水质、改善湖湾生态景观等重要作用 ${ }^{[1-2]}$. 河口湿地沉积物是氮、磷等污染物的存储库, 在外源得到控 制时, 沉积物在一定程度上能充当营养源的作用, 被吸附在沉积物中的营养物质能通过解析、溶解等作用返 回上覆水体, 形成湿地营养源的内负荷, 影响河口湿地水质和削减效果 ${ }^{[3-5]}$. 河口湿地不仅是削减人湖污染、 保护湖泊的最后屏障, 而且对控制湖泊富营养化具有重要作用. 因此, 河口湿地的治理和保护显得尤为重要. 当前, 我国学者对湖泊、水库沉积物碳、氮、磷和重金属污染进行了大量研究, 如王佩等 ${ }^{[6]}$ 研究了太湖湖滨带 底泥氮、磷、有机质的分布与污染评价; 赵兴青等 ${ }^{[7]}$ 采集了不同季节太湖梅梁湾和贡湖底泥柱样,研究了底 泥营养盐含量的垂直变化; 卢少勇等 ${ }^{[8]}$ 研究了长寿湖表层沉积物氮、磷和有机质污染特征并对其进行评价; 张清海等 ${ }^{[9]}$ 研究了贵州草海典型高原湿地表层沉积物重金属的积累、分布与污染评价; 赵海超等 ${ }^{[10]}$ 研究了 洱海沉积物中不同形态磷的时空分布特征; 陈永川等 ${ }^{[11]}$ 研究了滇池沉积物总磷 (TP) 的时空分布特征; 张玉 召等 ${ }^{[12]}$ 研究了阳宗海沉积物中磷的分布及其影响因素; 张娜等 ${ }^{[13]}$ 对青藏高原典型湖泊湖岸带表层沉积物 碳、氮、磷进行了分析; 但关于国内高原河口湿地沉积物碳、氮、磷的分布及污染现状的研究鲜见报道.

罗时江河口湿地位于云南高原湖泊洱海北部湖湾人水口处, 其在削减罗时江上游农业面源污染、控制 洱海湖泊富营养中发挥着重要作用. 近年来, 随着洱海流域旅游业、工业的发展, 外源污染加重, 罗时江河口 湿地沉积物积累了大量的污染物质, 在适当的条件下释放到水体中, 从而加剧了洱海的水体富营养化的风 险. 本研究通过对罗时江河口湿地不同分区和两条主水流通道沉积物的分析,揭示其总氮 ( TN)、TP 和有机 质 $(\mathrm{OM})$ 的分布特征并对其污染水平进行评价, 旨在系统全面阐明罗时江河口湿地沉积物污染现状及来源, 为罗时江河口湿地沉积物污染防治和生态环境保护提供科学依据.

\section{1 研究区概况}

罗时江发源于大理市洱源县西湖, 是洱海北部 3 条主要人湖河流之一, 流经右所、邓川 、上关三乡镇, 在 沙坪九孔桥注人洱海, 全长 $18.29 \mathrm{~km}$. 流量在丰水期约为 $13.0 \mathrm{~m}^{3} / \mathrm{s}$, 枯水期为 $2.0 \mathrm{~m}^{3} / \mathrm{s}$, 占洱海总来水量的 $13 \%$. 据本项目监测结果, 2013 年罗时江水质 TP 指标超过《地表水环境质量标准》 (GB 3838-2002) 中的 V 类标准 (年平均浓度为 $0.68 \mathrm{mg} / \mathrm{L}$ ), 无法满足《洱海流域保护治理规划 $(2003-2020) 》$ 所要求的 “ II 类标 准”.

罗时江河口湿地是削减罗时江携带的农业面源污染物、保护洱海水质的最后屏障,位于洱海北部湖湾 $\left(25^{\circ} 56^{\prime} 52.8^{\prime \prime} \sim 25^{\circ} 57^{\prime} 24.9^{\prime \prime} \mathrm{N}, 100^{\circ} 05^{\prime} 59.9^{\prime \prime} \sim 100^{\circ} 06^{\prime} 5.9^{\prime \prime} \mathrm{E}\right)$, 面积约 $0.5 \mathrm{~km}^{2}$. 研究区属北亚热带高原季风气候 区, 年均温度为 $15.6^{\circ} \mathrm{C}$, 年均降雨量约为 $942 \mathrm{~mm}$. 湿地西北和东北部分别有罗时江、黑泥沟携带大量的泥 沙、磷污染物注人. 湿地内植被多为人工栽植的水生植物, 其中挺水植物主要有芦苇 (Phragmites australis)、 荷 (Nelumbo nucifera)、梭鱼草 (Pontederia cordata)、再力花 (Thalia dealbata)、香蒲 (Typha orientalis Presl)、菰 (Zizania latifolia); 沉水植物主要有金鱼藻 (Ceratophyllum demersum)、微齿眼子菜 (Potamogeton maackianus)、 黑藻 (Hydrilla verticillata); 浮叶植物主要有睡莲 (Nymphaea) 等.

\section{2 研究方法}

\section{1 样品采集与分析}

本研究采用网格法布点,网格大小为 $100 \mathrm{~m} \times 100 \mathrm{~m}$, 去除无效网格(如整个网格中为小岛或无水淹没 区), 罗时江河口湿地中共划分为 45 个网格, 在网格中心处取样, 其中 $23^{\#} 、 28^{\#} 、 30^{\#} 、 31^{\#} 、 33^{\#} 、 34^{\#} 、 35^{\#} 、 36^{\#}$ 样 点网格由于被小岛分割, 未在网格中心取样, 根据地形条件及水流状况增加 1 2 个采样点, 增加后采样点共 有 55 个 (图 1). 原罗时江河流位置, 目前是罗时江河口湿地主水流通道 I (样点为: $1^{\#} 、 14^{\#} 、 25^{\#} 、 34 \mathrm{~A}^{\#} 、 38^{\#}$ ); 原黑泥沟河流位置, 目前是罗时江河口湿地主水流通道 II (样点为: $2^{\#} 、 3^{\#} 、 12^{*} 、 42^{*} 、 43^{*}$ ).

采样时间为 2014 年 11 月 20 日, 利用柱状底泥采样器采集 $0 \sim 10 \mathrm{~cm}$ 表层沉积物, 取样后放人便携式冷 恒温箱带回实验室分析沉积物中 TN、TP 和 OM 含量. 沉积物 TN 、 TP 和 OM 指标分析方法分别采用高氯酸- 
硫酸消化法 ( LY/T 1228-1999)、酸熔-钿锑抗比色法 ( LY/T 1232-1999) 和重铬酸钾氧化-外加热法 ( LY/T 1237-1999).
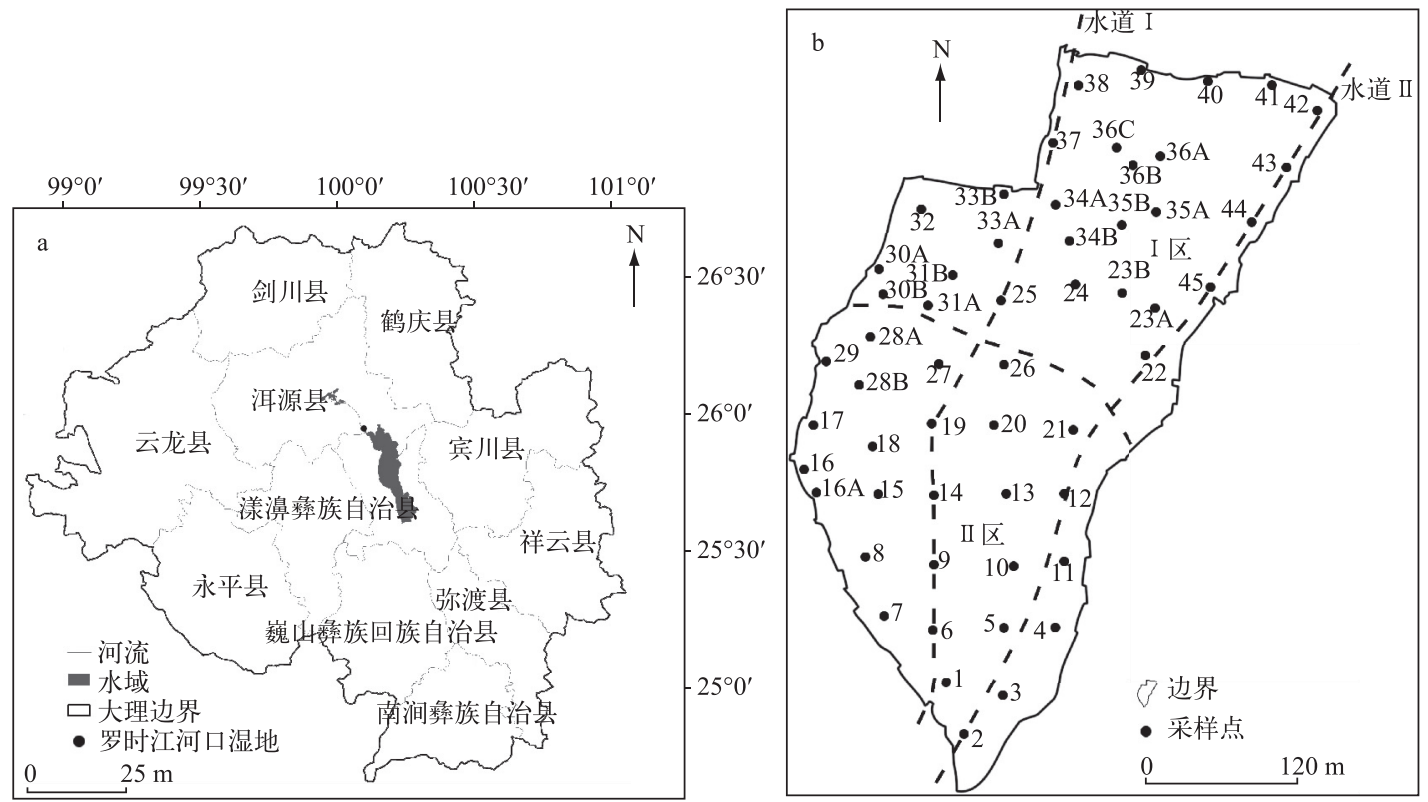

图 1 罗时江河口湿地区位(a) 及样点布置(b)

Fig.1 Location of study area(a) and sampling sites(b) in estuarine wetland of Luoshi River

\section{2 数据处理与分析}

数据处理及其相关分析采用 Excel 2007 与 SPSS 16.0 软件.

\section{3 结果与讨论}

\section{$3.1 \mathrm{OM}$ 分布特征}

$\mathrm{OM}$ 是沉积物是湖泊内源污染的重要指标, 也是反映有机营养程度的重要标志 ${ }^{[7,14]}$. 罗时江河口湿地沉 积物 $\mathrm{OM}$ 含量在 $32.43 \sim 233.03 \mathrm{~g} / \mathrm{kg}$ 之间, 平均值为 $78.54 \mathrm{~g} / \mathrm{kg}$, 平均值由高到低依次为: 水道 $\mathrm{I}<$ 水道 II , I 区 $<$ II 区. 水道 I 的 OM 含量最大值、最小值和 平均值分别为 $233.03 、 64.29$ 和 $94.08 \mathrm{~g} / \mathrm{kg}$; 水道 II 的 OM 含量最大值、最小值和平均值分别为 147.85 、 73.90 和 $96.84 \mathrm{~g} / \mathrm{kg}$; I 区的 OM 含量在32.43 233.03 $\mathrm{g} / \mathrm{kg}$ 之间,平均值为 $72.57 \mathrm{~g} / \mathrm{kg}$; II 区的 $\mathrm{OM}$ 含量在 $32.68 \sim 147.85 \mathrm{~g} / \mathrm{kg}$ 之间, 平均值为 $84.74 \mathrm{~g} / \mathrm{kg}$ (图 2 ). 易文利等 ${ }^{[15]}$ 研究认为长江中下游 11 个浅水湖泊 沉积物中 $\mathrm{OM}$ 含量在 $9.80 \sim 110.00 \mathrm{~g} / \mathrm{kg}$ 之间, 平均值 为 $37.20 \mathrm{~g} / \mathrm{kg}$; 赵海超等 ${ }^{[18]}$ 研究表明, 洱海表层沉积 物中 $\mathrm{OM}$ 含量在 $25.70 \sim 148.9 \mathrm{~g} / \mathrm{kg}$ 之间, 平均值为 $52.0 \mathrm{~g} / \mathrm{kg}$, 可见罗时江河口湿地表层沉积物中 $\mathrm{OM}$ 含 量较高, 潜在释放风险较高.

有资料显示,富营养化水体中沉积物中所含 $\mathrm{OM}$ 一般来自生活污水和水生动植物残体长期沉

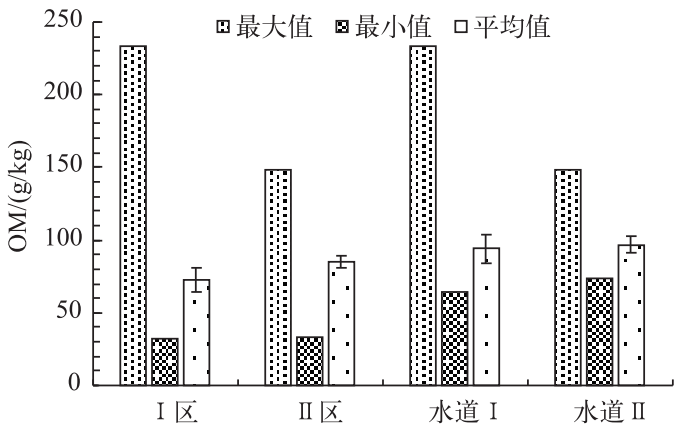

图 2 罗时江河口湿地表层沉积物 中 $\mathrm{OM}$ 含量的分布特征

Fig.2 Distribution of organic matter contents in the surface sediments of the estuarine wetland of Luoshi River 
积 ${ }^{[16-17]}$, 这些有机残体经过湿地生物的分解及矿化, 不断与水体发生交换, 逐步沉积和埋藏于沉积物中, 其 在湖泊营养盐交换过程中却起着举足轻重的作用 ${ }^{[18]}$. 罗时江河口湿地水道 II 和 II 区沉积物 OM 含量高于水 道 I 和 I 区, 可能与有机质长期沉降累积、水体流动性和船运等有关. II 区水域分布面积较宽, 水流从 I 区 水道急速流至 II 区, 水域变宽, 流速变缓, 沉积作用加剧使得沉积物 OM 含量较高. OM 含量的高低不仅与水 体沉积作用有关, 而且与人类的活动如船运、养殖活动等也有密切关系. 据现场调查, II 区和水道 II 为湿地 观光船的主要运行区域, 频繁的人为扰动促进了沉积物对 $\mathrm{OM}$ 的吸附. 此外, 在湿地恢复建设之前 II 区主要 为鱼塘养殖用地, 水产养殖会对沉积物 OM 产生影响, 太湖围栏养殖导致沉积物 OM 含量增加 $593 \%{ }^{[19]}$. 本 研究中水道 II 东北方向有从事养殖活动, 沉积物 OM 含量明显高于无养殖活动的水道 I.

\subsection{TN、TP 分布特征}

罗时江河口湿地表层沉积物 TN 含量在 $0.33 \sim 2.96 \mathrm{~g} / \mathrm{kg}$ 之间, 平均值变化为: I 区 $>$ II 区, 水道 I > 水道 II. 根据美国环境保护署 (EPA) 制定的沉积物 TN 污染的评价标准 ${ }^{[20]}$, II 区和水道 II 的 TN 平均值小于 1.00 $\mathrm{g} / \mathrm{kg}$, 属轻度污染; I 区和水道 I 的 TN 含量在 $1.00 \sim 2.00 \mathrm{~g} / \mathrm{kg}$ 之间, 属中度污染(图 3).

罗时江河口湿地表层沉积物 TP 含量在 $0.04 \sim 1.28 \mathrm{~g} / \mathrm{kg}$ 之间, 平均值为 $0.57 \mathrm{~g} / \mathrm{kg}$, 平均值变化为: II 区> $\mathrm{I}$ 区, 水道 I > 水道 II. 根据美国 $\mathrm{EPA}$ 制定的沉积物 TP 污染的评价标准 ${ }^{[20]}$, I 区、 II 区和水道 I 的 TP 平均 值在 $0.45 \sim 0.65 \mathrm{~g} / \mathrm{kg}$ 之间, 属中度污染; 水道 II 的 TP 含量在 $0.45 \mathrm{~g} / \mathrm{kg}$ 以下, 属轻度污染 (图 3 ).
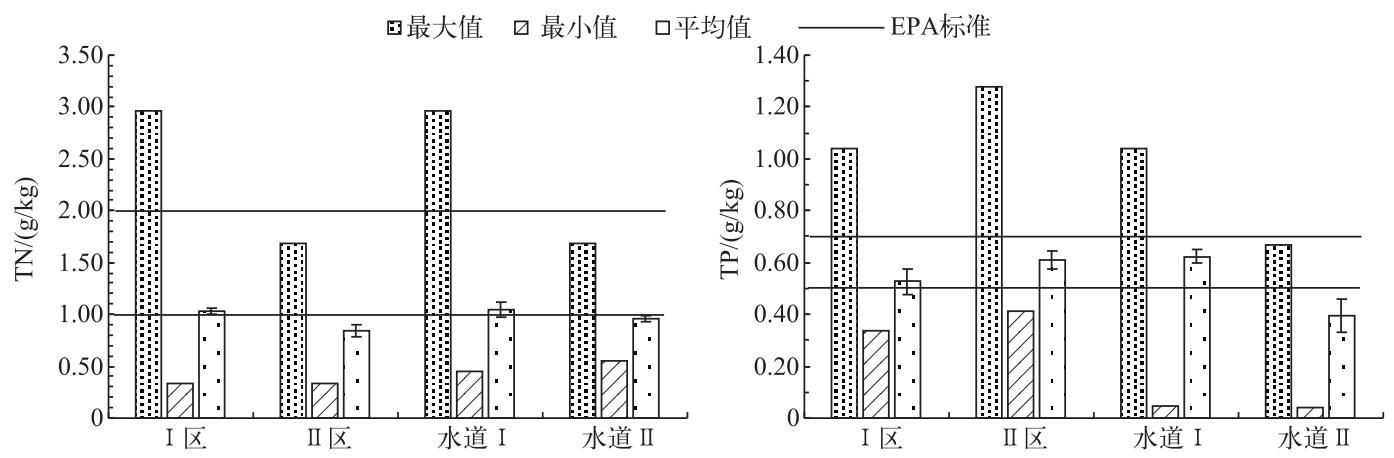

图 3 罗时江河口湿地表层沉积物中 TN 和 TP 含量的分布特征

Fig.3 Distributions of TN and TP contents in the surface sediments of the estuarine wetland of Luoshi River

沉积物中 TN 和 TP 含量的分布是外源污染物输人后在水体动力作用下在不同区域沉降的结果, 同时沉 积后的氮素在水体扰动下会发生悬浮再分配 ${ }^{[21-22]}$. 氮素在生物及 $\mathrm{pH} 、 \mathrm{DO}$ 等环境因子作用下发生形态转化, 逐步向下沉积或释放到水体中被生物吸收利用 ${ }^{[23-25]}$. 杨洋等 ${ }^{[3]}$ 的研究表明, 水草存在与否和沉积物氮含量 呈显著正相关, 而罗时江河口湿地 I 区挺水植物分布面积较 II 区大, 故 I 区表层沉积物 TN 含量大于 II 区. 与 TN 相反, I 区表层沉积物的 TP 含量小于 II 区, 这可能是由于水草的分布及其生物量大小能影响湖泊沉 积物氮、磷元素含量, 氮含量均随着水草生物量的增加而显著增加,但水草生物量对磷含量的影响微乎其 微 ${ }^{[26]}$, 甚至能明显降低磷含量. 有研究表明, 挺水植物降低内源磷的能力较沉水植物强 ${ }^{[27]}$. 而现场调查发 现, I 区以挺水植物为主, II 区以沉水植物为主,所以导致 I 区表层沉积物的 TP 含量小于 II 区.

表层沉积物中 TN 和 TP 含量均是水道 I > 水道 II ( 图 3). 一方面是由于水道 II 水较深且无植物, 上游来 水所受阻力小, 流速相对较快, 污染物沉积作用相对水道 I 较弱; 另一方面, 通过对 $38^{\#}$ 和 $42^{\#}$ (分别为水道 I 和水道 II 人水口处) 样点 12 个月的水质分析发现, 12 个月中有 9 个月 $38^{\#}$ 样点水体 TN 、 TP 浓度较 $42^{\#}$ 样点 的高 $(P<0.01)$ ( 图 4), 表明外源氮、磷输人以水道 I 为主. 由此可以推断, 沉积物氮、磷的空间分布受外源输 人的影响.

\section{4 罗时江河口湿地表层沉积物污染评价}

目前对浅水湖泊沉积物的污染状况尚无统一的评价方法和标准, 多用有机指数 $(O I)$ 和有机氮 $(O N)$ 评 
价法 ${ }^{[28]}$, 只考虑了 $\mathrm{OM}$ 和 $\mathrm{ON}$, 而忽略了磷; 有的 采用加拿大安大略省环境和能源部 (1992 年) 制 定的环境质量评价标准 ${ }^{[29-33]}$, 该标准根据底泥中 污染物对底栖生物的生态毒性效应进行分级, 虽 然后者考虑到磷,但此标准源于对海洋底泥的生 态毒性分析. 因此本文针对罗时江河口湿地表层 沉积物的氮、磷和 OM 的分布特点, 用综合污染指 数评价法和有机指数评价法来评价罗时江河口湿 地表层沉积物的污染现状.

\section{1 综合污染指数评价}

本文以采用的 $\mathrm{TN}$ 和 $\mathrm{TP}$ 的评价标准 ( 0.55 和 $0.60 \mathrm{~g} / \mathrm{kg})$, 与加拿大安略省环境和能源部

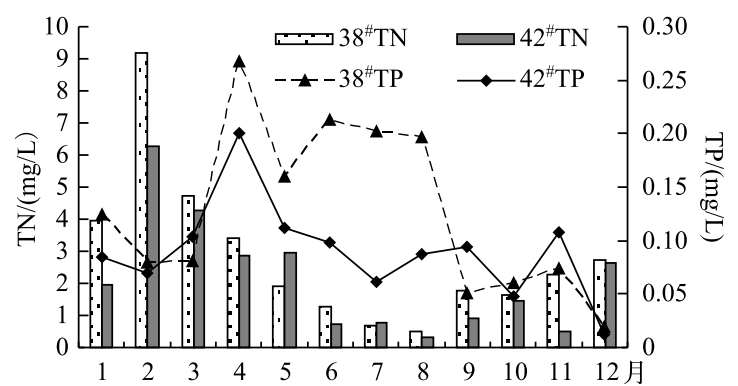

图 $438^{\#}$ 和 $42^{\#}$ 样点水体中总氮和总磷浓度

Fig.4 Total nitrogen and total phosphorus concentrations of $38^{\#}$ and $42^{\#}$ sampling sites

(1992) 发布的指南中沉积物中能引起最低级别生态风险效应的 TN 和 TP 含量相一致 ${ }^{[32]}$. 单项污染指数计 算公式为 ${ }^{[34]}$ :

$$
\begin{gathered}
S_{i}=C_{i} / C_{\mathrm{s}} \\
F F=\sqrt{\frac{F^{2}+F_{\text {max }}^{2}}{2}}
\end{gathered}
$$

式中, $S_{i}$ 为单项评价指数或标准指数, $S_{i}>1$ 表明含量超过评价标准值; $C_{i}$ 为评价因子 $i$ 的实测值 $(\mathrm{g} / \mathrm{kg}) ; C_{\mathrm{s}}$ 为 评价因子 $i$ 的评价标准值 $\left(\mathrm{g} / \mathrm{kg}\right.$ ). TN 的 $C_{\mathrm{s}}$ 为 $0.55 \mathrm{~g} / \mathrm{kg}$, TP 的 $C_{\mathrm{s}}$ 为 $0.60 \mathrm{~g} / \mathrm{kg}^{[35]} ; F F$ 为综合污染指数; $F$ 为 $n$ 项污染物污染指数平均值 ( $S_{\mathrm{TN}}$ 和 $S_{\mathrm{TP}}$ 的平均值); $F_{\text {max }}$ 为最大单项污染指数 ( $S_{\mathrm{TN}}$ 和 $S_{\mathrm{TP}}$ 的最大值). 罗时江河口 湿地表层沉积物氮、磷污染评价及污染程度分级结果见表 1 和表 2.

表 1 罗时江河口湿地表层沉积物综合污染评价*

Tab.1 Comprehensive pollution assessment for the surface sediments of the estuarine wetland of Luoshi River

\begin{tabular}{lcccccc}
\hline 项目 & $S_{\mathrm{TN}}$ & 等级 & $S_{\mathrm{TP}}$ & 等级 & $F F$ & 等级 \\
\hline I 区 & 1.91 & 3 & 0.88 & 2 & 1.67 & 3 \\
II 区 & 1.53 & 3 & 1.02 & 3 & 3 & 1.41 \\
水道 I & 1.89 & 3 & 1.04 & 2 & 1.69 & 3 \\
水道 II & 1.74 & 3 & 0.66 & 1.49 & 2 \\
\hline
\end{tabular}

*评价标准参照文献 $[36]$.

表 2 罗时江河口湿地表层沉积物综合污染程度分级

Tab.2 Standard and level of comprehensive pollution for the surface sediments of the estuarine wetland of Luoshi River

\begin{tabular}{ccccc}
\hline 等级 & $S_{\mathrm{TN}}$ & $S_{\mathrm{TP}}$ & $F F$ & 类型 \\
\hline 1 & $S_{\mathrm{TN}}<1.0$ & $S_{\mathrm{TP}}<0.5$ & $F F<1.0$ & 清洁 \\
2 & $1.0 \leqslant S_{\mathrm{TN}} \leqslant 1.5$ & $0.5 \leqslant S_{\mathrm{TP}} \leqslant 1.0$ & $1.0 \leqslant F F \leqslant 1.5$ & 轻度污染 \\
3 & $1.5<S_{\mathrm{TN}} \leqslant 2.0$ & $1.0<S_{\mathrm{TP}} \leqslant 1.5$ & $1.5<F F \leqslant 2.0$ & 中度污染 \\
4 & $S_{\mathrm{TN}}>2.0$ & $S_{\mathrm{TP}}>1.5$ & $F F>2.0$ & 重度污染 \\
\hline
\end{tabular}

根据表 1 中综合污染指数, 可得到罗时江河口湿地表层沉积物的污染分布 (图 5). 结合表 2 和图 5 可知 综合污染指数大小为: I 区 > II 区, 水道 I > 水道 II , 且 I 区和水道 I 均属于中度污染, II 区和水道 II 均属于 轻度污染.

\section{2 有机污染指数评价}

综合污染指数法忽略了 OM 指标, 考虑到近年来沉积物富营养化最主要的原因是有机物、氮、磷的迅速 


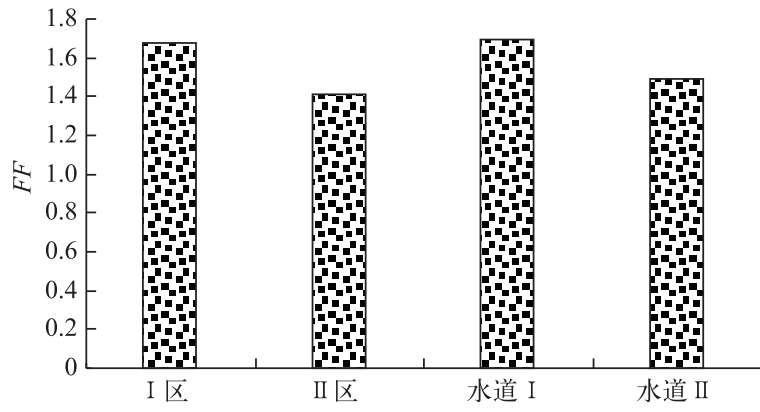

图 5 罗时江河口湿地表层沉积物的综合污染分布

Fig.5 Distribution of comprehensive pollution for the surface sediments of the estuarine wetland of Luoshi River
增加,所以本文用有机污染指数法 ${ }^{[37]}$ 对罗时江 河口湿地沉积物污染现状进一步评价, 使评价 结果更完善. 有机污染指数评价法将选用的评 价参数 TN、TP 综合成一个概括的指数值来表 征底泥污染程度, 其相对于综合污染指数法而 言具优越性, 是综合信息输出 ${ }^{[38]}$. 根据公式 (3) (5) 并结合表 3, 罗时江河口湿地表层沉 积物有机污染评价结果见表 4.

$$
\begin{gathered}
O I=\mathrm{OC}(\%) \times \mathrm{ON}(\%) \\
\mathrm{ON}=\mathrm{TN}(\%) \times 0.95 \\
\mathrm{OC}=\mathrm{OM}(\%) / 1.724
\end{gathered}
$$

式中, $O C$ 为有机碳.

表 3 罗时江河口湿地表层沉积物的有机指数评价标准

Tab.3 Assess standards of organic index for the surface sediments of the estuarine wetland of Luoshi River

\begin{tabular}{rcccc}
\hline 项目 & $O I<0.05$ & $0.05 \leqslant O I<0.20$ & $0.2 \leqslant 0 I<0.5$ & $O I \geqslant 0.5$ \\
\hline 类型 & 清洁 & 轻度污染 & 中度污染 & 重度污染 \\
等级 & I & II & III & IV \\
\hline
\end{tabular}

表 4 罗时江河口湿地表层沉积物的有机污染评价

Tab.4 Organic pollution assessment for the surface sediments of the estuarine wetland of Luoshi River

\begin{tabular}{rcccc}
\hline 项目 & OC/\% & ON/\% & OI & 等级 \\
\hline I 区 & 0.41 & 1.00 & 0.41 & III \\
II 区 & 0.47 & 0.80 & 0.38 & III \\
水道 I & 0.55 & 0.99 & 0.55 & IV \\
水道 II & 0.56 & 0.91 & 0.51 & IV \\
\hline
\end{tabular}

罗时江河口湿地有机污染分布情况为: I 区 $>$ II 区, 水道 I > 水道 II , 总体为中度污染, 局部 (水道 I 和水 道 II ) 属于重度污染 (表 4).

$F F$ 和 $O I$ 的评价结果较为一致, 罗时江河口湿地沉积物均表现为 I 区 $>$ II 区, 水道 I $>$ 水道 II. FF 指数 表明, 水道 I 和 I 区属于中度污染水平, 水道 II 和 II 区均属于轻度污染水平; $O I$ 指数表明, I 区和 II 区均属 于中度污染, 水道 I 和水道 II 均属于重度污染水平. 综上所述, 该湿地表层沉积物综合污染和有机污染水平 处于轻度与中度污染等级之间. 与石勇 ${ }^{[39]}$ 对巢湖塘西河河口湿地 (总体上属于警戒等级, 处于尚清洁水 平)、陈如海等 ${ }^{[28]}$ 对西溪湿地 (富营养化程度比较严重) 沉积物污染的评价结果相比, 罗时江河口湿地表层 沉积物污染水平与平原湿地存在差异.

\section{5 结论}

罗时江河口湿地表层沉积物 TN 空间分布情况为I区 >II区, 水道I $>$ 水道II, TN 含量在 $0.33 \sim 2.96 \mathrm{~g} / \mathrm{kg}$ 之间, 平均值为 $0.94 \mathrm{~g} / \mathrm{kg}$; TP 含量在 $0.04 \sim 1.28 \mathrm{~g} / \mathrm{kg}$ 之间, 平均值为 $0.57 \mathrm{~g} / \mathrm{kg}$, 空间分布情况为: I 区 $<$ II 区, 水道 $\mathrm{I}>$ 水道 II ; OM 含量在 $32.43 \sim 233.03 \mathrm{~g} / \mathrm{kg}$ 之间, 平均值为 $78.54 \mathrm{~g} / \mathrm{kg}$, 与 TN 和 TP 的空间分布不同, OM 含 量表现为: 水道 I $<$ 水道 II, I 区 $<$ II 区.

沉积物氮、磷分布受外源输人影响, 且罗时江河口湿地氮、磷污染主要来自水道 I 和水道 II. 养殖活动 导致沉积物 OM 含量增加, 对 TP 影响不显著. 大量挺水植物分布会增加沉积物中总氮含量, 降低总磷含量. 运用 $F F$ 分析表明: I 区和水道 I 均属于中度污染, II 区和水道 II 均属于轻度污染; 运用 $O I$ 分析表明: I 区 
和 II 区均属于中度污染, 水道 I 和水道 II 均属于重度污染. $F F$ 和 $O I$ 的评价结果均表现为 I 区 $>$ II 区, 水道 I > 水道 II . 通过分析比较, 罗时江河口湿地与平原地区湿地表层沉积物污染水平存在差异.

\section{6 参考文献}

[ 1 ] Cui Baoshan, Liu Xingtu. Discussion on some basic problems in design of wetland ecosystem. Chinese Journal of Applied Ecology, 2001, 12(1) : 145-150. [崔保山, 刘兴土. 湿地生态系统设计的一些基本问题探讨. 应用生态学报, 2001, 12(1) : 145-150.]

[ 2 ] Li Yinxi, Hu Yaohui, Wang Yunhua et al. Wetland restoration and its purification efficiency in estuary of Dajie River, Lake Xingyun, Yunnan Province. J Lake Sci, 2007, 19(3) : 283-288. DOI: 10.18307/2007.0309. [李荫胥, 胡耀辉, 王云华等. 云南星云湖大街河口湖滨湿地修复及净化效果. 湖泊科学, 2007, 19(3) : 283-288.]

[ 3 ] Yang Yang, Liu Qigen, Hu Zhongjun et al. Spatial distribution of sediment carbon, nitrogen and phosphorus and pollution evaluation of sediment in Taihu Lake Basin. Acta Scientiae Circumstantiae, 2014, 34(12) : 3057-3064. [杨洋, 刘其根, 胡忠军等. 太湖流域沉积物碳氮磷分布与污染评价. 环境科学学报, 2014, 34(12): 3057-3064.]

[ 4 ] Bootsma MC, Barendregt A, Alphen JCA. Effectiveness of reducing external nutrient load entering a eutrophicated shallow lake ecosystem in the Naardermeer nature reserve, the Netherlands. Biological Conservation, 1999, 90(3) : 193-201.

[ 5 ] Xu Jin, Xu Ligang, Gong Ran et al. Adsorption and release characteristic of phosphorus and influential factors in Poyang Lake sediment. Ecology and Environment Sciences, 2014, 23(4):630-635. [徐进, 徐力刚, 龚然等. 鄱阳湖沉积物中 磷吸附释放特性及影响因素研究. 生态环境学报, 2014, 23(4) : 630-635.]

[ 6 ] Wang Pei, Lu Shaoyong, Wang Dianwu et al. Nitrogen, phosphorous and organic matter spatial distribution characteristics and their pollution status evaluation of sediments nutrients in lakeside zones of Taihu Lake. China Environmental Science, 2012, 32(4) : 703-709. [王佩, 卢少勇, 王殿武等. 太湖湖滨带底泥氮、磷、有机质分布与污染评价. 中国环境科 学, 2012, 32(4): 703-709.]

[ 7 ] Zhao Xingqing, Yang Liuyan, Yu Zhenyang et al. Temporal and spatial distribution of physicochemical characteristics and nutrients in sediments of Lake Taihu. J Lake Sci, 2007, 19(6) : 698-704. DOI:10.18307/2007.0612. [赵兴青, 杨柳 燕, 于振洋等. 太湖沉积物理化性质及营养盐的时空变化. 湖泊科学, 2007, 19(6) : 698-704.]

[ 8 ] Lu Shaoyong, Xu Mengsuang, Jin Xiangcan et al. Pollution characteristics and evaluation of nitrogen, phosphorus and organic matter in surface sediments of Lake Changshouhu in Chongqing, China. Chinese Journal of Environmental Science, $2012,33(2): 393-398$. [卢少勇, 许梦爽, 金相灿等. 长寿湖表层沉积物氮磷和有机质污染特征及评价. 环境科 学, 2012, 33(2) : 393-398.]

[ 9 ] Zhang Qinghai, Lin Changhu, Tan Hong et al. Accumulation, distribution and pollution assessment of heavy metals in surface sediment of Caohai Plateau Wetland, Guizhou Province. Environmental Science, 2013, 34(3): 1055-1061. [张清 海, 林昌虎, 谭红等. 草海典型高原湿地表层沉积物重金属的积累、分布与污染评价. 环境科学, 2013, 34(3): 1055-1061.]

[10] Zhao Haichao, Wang Shengrui, Jiao Lixin et al. Characteristics of temporal and spatial distribution of different forms of phosphorus in the sediments of Erhai Lake. Research of Environmental Sciences, 2013, 26(3): 227-234. [ 赵海超, 王圣 瑞, 焦立新等. 洱海沉积物中不同形态磷的时空分布特征. 环境科学研究, 2013, 26(3) : 227-234.]

[11] Chen Yongchuan, Tang Li, Zhang Degang et al. The spatially and temporally dynamic variation of total phosphorus in sediment of Dianchi Lake. Journal of Agro-Environment Science, 2007, 26(1): 51-57. [陈永川, 汤利, 张德刚等. 滇池沉 积物总磷的时空分布特征研究. 农业环境科学学报, 2007, 26(1) : 51-57.]

[12] Zhang Yuxi, Liu Jingtao, Wang Jincui et al. Distribution of phosphorus in the sediments of Yangzonghai Lake and its influencing factors. Safety and Environmental Engineering, 2013, 20(6) : 43-48. [张玉秃, 刘景涛, 王金翠等. 阳宗海沉积 物中磷的分布及其影响因素. 安全与环境工程, 2013, 20(6): 43-48.]

[13] Zhang Na, Li Hongjing, Yuan Lingwei et al. Characteristics of organic carbon, nitrogen and phosphorus in surface sediments of typical littorals of three lake regions on Qinghai-Tibet Plateau. Journal of Shaanxi Normal University ( Natural Science Edition), 2010, 14(3): 70-75. [张娜, 李红敬, 远凌威等. 青藏高原典型湖泊湖岸带表层沉积物碳、氮、磷分 析. 陕西师范大学学报: 自然科学版, 2010, 14(3): 70-75.]

[14] Yu Hui, Zhang Wenbin, Lu Shaoyong et al. Spatial distribution characteristics of surface sediments nutrients in Lake 
Hongze and their pollution status evaluation. Environmental Science, 2010, 31(4): 961-968. [余辉, 张文斌, 卢少勇等. 洪泽湖表层底质营养盐的形态分布特征与评价. 环境科学, 2010, 31(4)：961-968.]

[15] Yi Wenli, Wang Shengrui, Jin Xiangcan et al. Distribution of total organic matter and the forms on the sediments from shallow lakes in the middle and lower reaches of the Yangtze River. Journal of Northwest University ( Natural Science Edition), 2008, 36(5): 141-148. [ 易文利, 王圣瑞, 金相灿等. 长江中下游浅水湖沉积物中有机质及其组分的赋存 特征. 西北农林科技大学学报: 自然科学版, 2008, 36(5): 141-148.]

[16] Tan Zhen. Vertical changes of nutrients in the sediments of urban lakes in Guangdong[ Dissertation]. Guangzhou: Jinan University, 2006. [谭镇. 广东城市湖泊沉积物营养盐垂直变化特征研究 [学位论文]. 广州: 暨南大学, 2006.]

[17] Li Wenchao. Nitrogen accumulation in the sediment of East Taihu Lake and biological sedimentation of aquatic plants. China Environmental Science, 1997, 17(5): 418-421. [李文朝. 东太湖沉积物中氮的积累与水生植物沉积. 中国环境 科学, $1997,17(5): 418-421$.

[18] Zhao Haichao, Wang Shengrui, Jiao Lixin et al. Characteristics of composition and spatial distribution of organic matter in the Sediment of Erhai Lake. Research of Environmental Sciences, 2013, 26(3): 243-249. [赵海超, 王圣瑞, 焦立新等. 洱海沉积物有机质及其组分空间分布特征. 环境科学研究, 2013, 26(3): 243-249.]

[19] Yang Qingxin, Li Wenchao. Environmental changes since foundation of pen-fish-farming in East Taihu Lake. China Environmental Science, 1996, 16(2) : 101-106. [杨清心, 李文朝. 东太湖围网养鱼后生态环境的演变. 中国环境科学, $1996,16(2): 101-106$.

[20] A guidance manual to support the assessment of contaminated sediments in freshwater ecosystems. US. EPA, 2002.

[21] Sun Xiaojing, Qin Boqiang, Zhu Guangwei et al. Release of colloidal N and P from sediment of lake caused by continuing hydrodynamic disturbance. Environmental Science, 2007, 28(6): 1223-1229. [孙小静, 秦伯强, 朱广伟等. 持续水动 力作用下湖泊底泥胶体态氮、磷的释放. 环境科学, 2007, 28(6): 1223-1229.]

[22] Zhang Yunlin, Qin Boqiang, Chen Weimin et al. A study on total suspended matter in Lake Taihu. Resources and Environment in the Yangtze Basin, 2004, 13(3) : 266-271. [张运林, 秦伯强, 陈伟民等. 太湖水体中悬浮物研究. 长江流域 资源与环境, 2004, 13(3): 266-271.]

[23] Beutel MW, Leonard TM, Dent SR et al. Effects of aerobic and anaerobic conditions on P, N, Fe, Mn, and Hg accumulation in waters overlaying profundal sediments of an oligo-mesotrophic lake. Water Research, 2008, 42(8/9) : 1953-1962.

[24] Liu JJ, Wang JQ, Xu WX. Effects of environmental factors on $\mathrm{NH}_{4}^{+}$release in sediments from Chaohu Lake. Agricultural Science \& Technology, 2008, 9(3): 153-156.

[25] Pan Qikun, Luo Zhuanxi, Qiu Zhaozheng et al. Distribution characteristics of nitrogen forms in surface sediments of Jiulongjiang Estuary Wetland. Research of Environmental Sciences, 2011, 24(6): 673-678. [潘齐坤, 罗专溪, 邱昭政等. 九龙江口湿地表层沉积物氮的形态分布特征. 环境科学研究, 2011, 24(6): 673-678.]

[26] Squires MM, Lesack LF. The relation between sediment nutrient content and macrophyte biomass and community structure along a water transparency gradient among lakes of the Mackenzie Delta. Canadian Journal of Fisheries and Aquatic Sciences, 2003, 60(3) : 333-343.

[27] Horppila J, Nurminen L. Effects of different macrophyte growth forms on sediment and P resuspension in a shallow lake. Hydrobiologia, 2005, 545(1): 167-175.

[28] Chen Ruhai, Zhan Liangtong, Chen Yunmin et al. Contents of nitrogen, phosphorus and organic materials in sediments and their distribution along depth at Xixi Wetland. China Environmental Science, 2010, 30(4) : 493-498. [陈如海, 詹良 通，陈云敏等. 西溪湿地底泥氮、磷和有机质含量坚向分布规律. 中国环境科学, 2010, 30(4): 493-498.]

[29] Calmano W, Ahlf W, Forstner U. Sediments quality assessment: Chemical and biological approaches. Berlin : Springer, 1996: 1-35.

[30] Wu Ming, Shao Xuexin, Jiang Keyi. Characteristics and assessment on nutrient distribution in water and sediments of Xixi National Wetland Park in Hangzhou. Forest Research, 2008, 21(4): 587-591. [吴明, 邵学新, 蒋科毅. 西溪国家湿地 公园水体和底泥 N-P 营养盐分布特征及评价. 林业科学研究, 2008, 21(4) : 587-591.]

[31] Leivuori M, Niemisto L. Sedimentation of trace metals in the Gulf of Bothnia. Chemosphere, 1995, 31 ( 8) : 3839-3856.

[32] Wei Linying, Bu Xianwei. Present assessment of environmental quality in sea area near Daao, Liuheng Island. Donghai Marine Science, 1991, 17(1): 66-71. [魏琳瑛, 卜献卫. 六横大乔附近海域环境质量现状评价. 东海海洋, 1991, $17(1): 66-71$. 
[33] Fang Yuqiao, Qiu Zu'nan, Ma Meifang et al. Enactment of the standard concerning polluted sediment types in the rivers. Environmental Science, 1989, 10(1): 27-30. [方宇翘, 垗祖楠, 马梅芳等. 河流底泥污染类型标准的制定. 环境科 学, 1989, 10(1): 27-30.]

[34] Yue Weizhong, Huang Xiaoping, Sun Cuici. Distribution and pollution of nitrogen and phosphorus in surface sediments from the pearl river estuary. Oceanologia et Limnologia Sinica, 2007, 38(2): 111-117. [岳维忠, 黄小平, 孙翠慈. 珠 江口表层沉积物中氮、磷的形态分布特征及污染评价. 海洋与湖沼, 2007, 38(2) : 111-117.]

[35] Wang Sumin, Dou Hongshen eds. Chinese lakes record. Beijing: Science Press, 1998. [王苏民, 窦鸿身. 中国湖泊志. 北京: 科学出版社, 1998.]

[36] Fan Zhijie. Study on definition of marine sediment criteria by equilibrium partitioning method. Environmental Protection in Transportation, 1999, 20(1) : 21-25. [范志杰. 浅谈海洋沉积物标准的几个问题. 交通环保, 1999, 20(1) : 21-25.]

[37] Li Renwei, Li He, Li Yuan et al. Study of heavy metals, nitrogen and phosphorus contaminants in the sediments of the Yellow River Delta in the sediments of the Yellow River Delta. Acta Sedimentologica Sinica, 2001, 19(4): 622-629. [李 任伟, 李禾, 李原等. 黄河三角洲沉积物重金属、氮和磷污染研究. 沉积学报, 2001, 19(4): 622-629.]

[38] Ding Jing. Characteristics of nitrogen and phosphorus distribution in Taihu Lake and its adsorption/desorption characteristics of the study[Dissertation]. Nanjing: Nanjing University of Science and Technology, 2010. [丁静. 太湖氮磷分布特 征及其吸附/解吸特征研究 [学位论文]. 南京: 南京理工大学, 2010.]

[39] Shi Yong. Pollution characteristics analysis and environmental quality assessment of sediments for estuary wetland of Tangxihe River [Dissertation]. Hefei: Hefei University of Technology, 2010. [石勇. 巢湖塘西河河口湿地沉积物污染特征 及环境质量评价 [学位论文]. 合肥: 合肥工业大学, 2009.] 